\title{
Mantle xenoliths of the Nyurbinskaya pipe (Yakutia): relicts of weakly metasomatized lithospheric mantle
}

\author{
Liudmila I. Sablukova ${ }^{1}$, Sergey M. Sablukov ${ }^{1}$, Yury B. Stegnitsky ${ }^{2}$ and Valery I. Banzeruk ${ }^{3}$ \\ ${ }^{1}$ RUSGEO Ltd, Moscow, Russia, \\ ${ }^{2}$ YaNIGP TsNIGRI ALROSA Co. Ltd., Mirny, Russia, \\ ${ }^{3}$ Nyurbinskaya Mine ALROSA Co. Ltd., Mirny, Russia
}

Mantle xenoliths abound in rocks related to all intrusion phases in the Nyurbinskaya pipe, varying in size from $2-6 \mathrm{~cm}$ to $21 \mathrm{~cm}(3.5 \mathrm{~kg}$ weight $)$. In all, more than 240 nodules were examined.

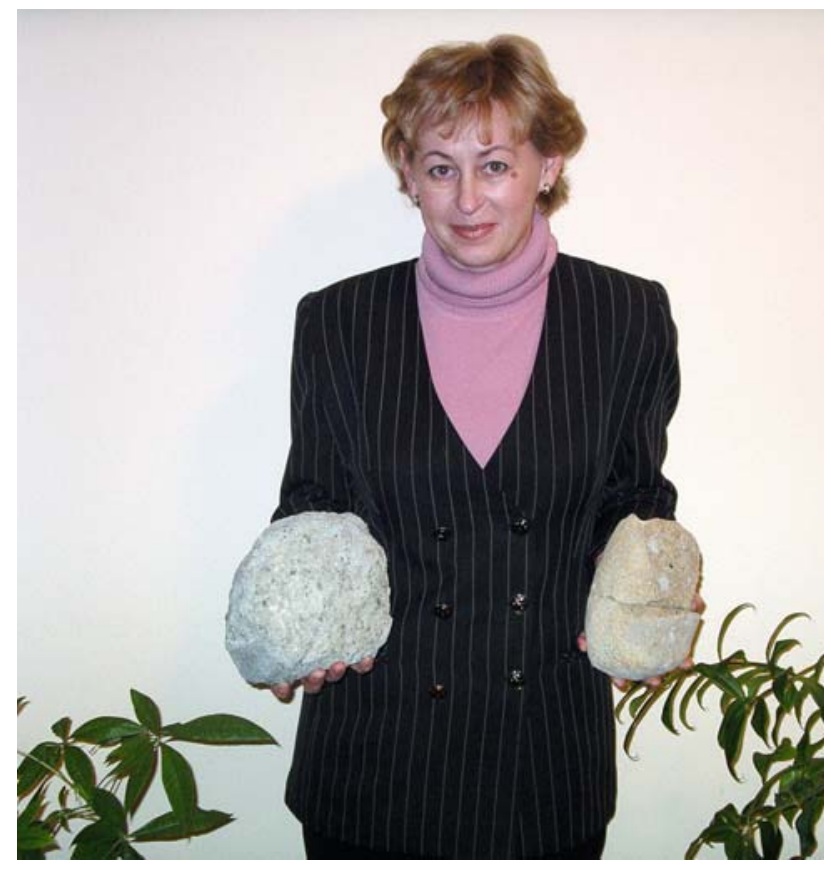

The most significant inclusions

The xenoliths are dominated by garnet peridotite and clinopyroxenite and chrome spinel peridotite, with a minor proportions of spinel peridotite and eclogite (Groups A and B). In addition, rare megacrysts of orange Ti-association garnet and macrocrystals of orange and red garnet (eclogite suite) also occur. Mantle xenoliths have a granulose structure. Cataclastic peridotite is almost completely lacing, while banded (layered) rocks and rocks with unbalanced mineral suites are quite abundant. Approximately $10 \%$ of garnet peridotite and clinopyroxenite xenoliths contain picroilmenite.
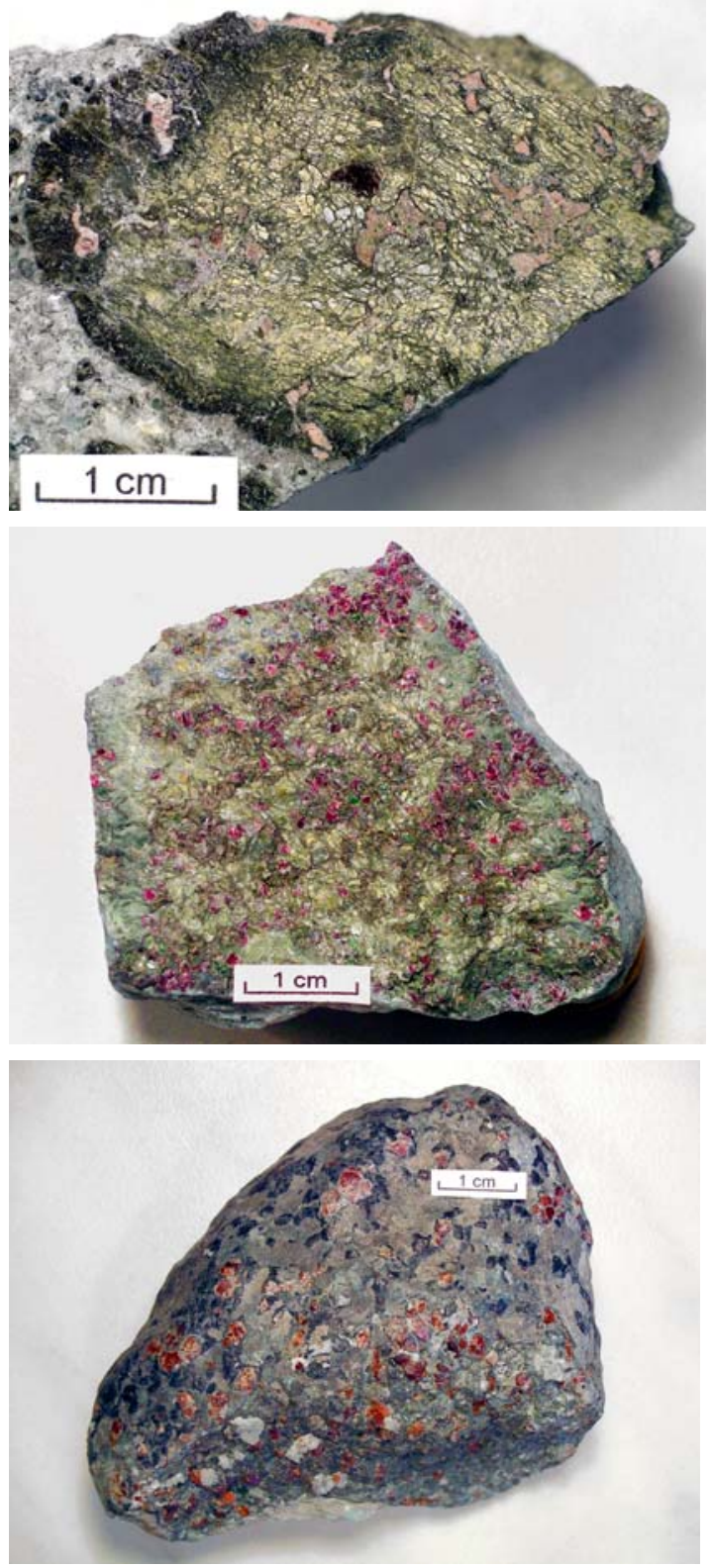

Mantle xenoliths: Cr-spinel peridotite (top), garnet peridotite (middle), eclogite (bottom). 


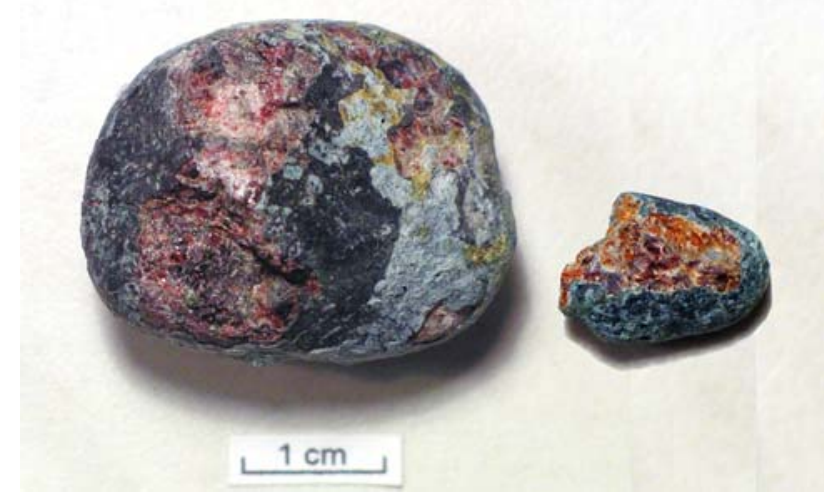

Eclogitic (left) and Ti-association (right) garnet megacrysts.

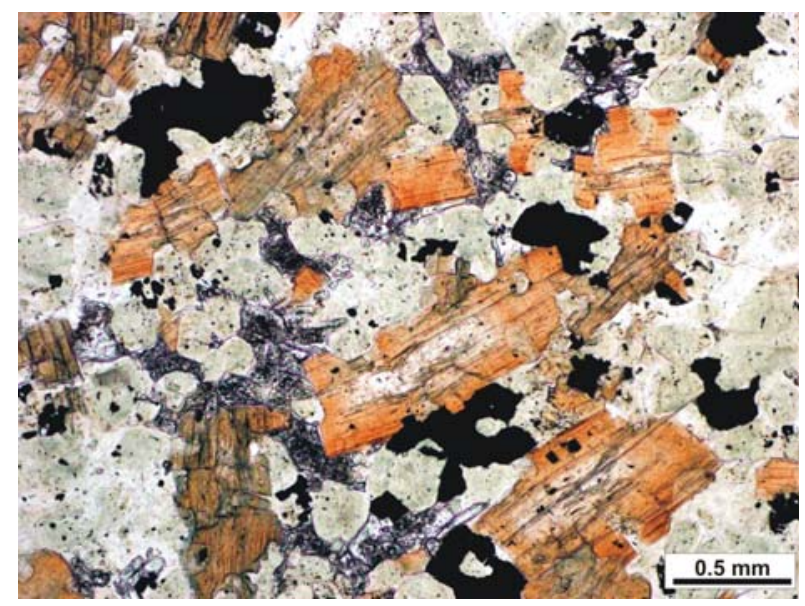

Xenolith of the apatite-ilmenite-olivine-phlogopite rocks: think section. Polarized light.

Chrome spinel from garnet-containing and chrome spinel peridotite is characterized by a high $\mathrm{Cr}_{2} \mathrm{O}_{3}$ content (45-62\% wt. \%), lower than average $\mathrm{FeO}$ and $\mathrm{TiO}_{2}$ contents, and a characteristic $\mathrm{Cr}^{3+} \Leftrightarrow \mathrm{Al}^{3+}$ isomorphism.

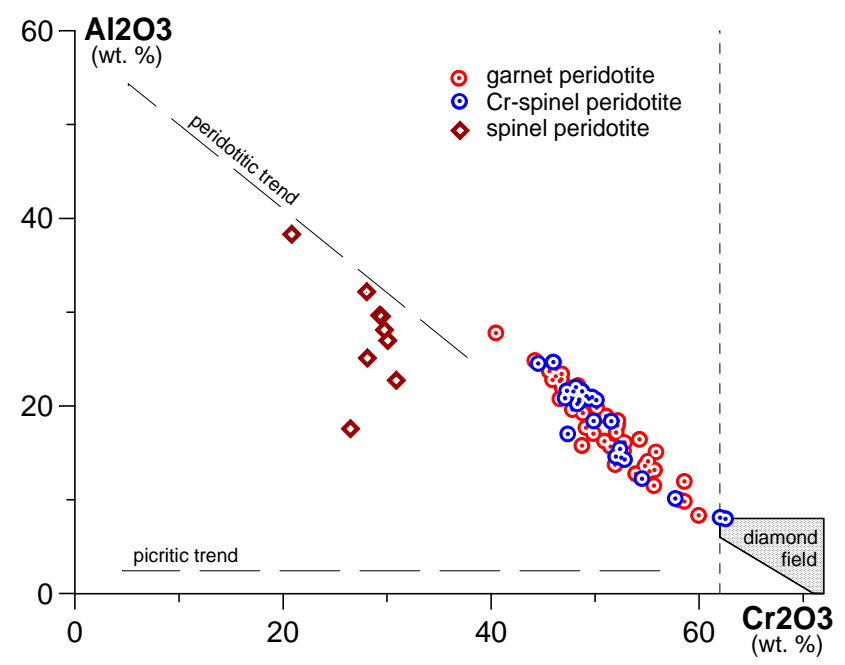

Chemical composition of the chrome spinel
Spinel peridotite xenoliths form an isolated group, with chrome spinel corresponding in composition to the low-pressure dept facies (less than 30 wt. $\% \mathrm{Cr}_{2} \mathrm{O}_{3}$ ).

Garnet from garnet peridotite and clinopyroxenite varies in composition, primarily in $\mathrm{Cr}_{2} \mathrm{O}_{3}$ content $(0.1$ 9 wt. \%), with medium-Cr and low-Fe lherzolite suite garnet varieties predominating.

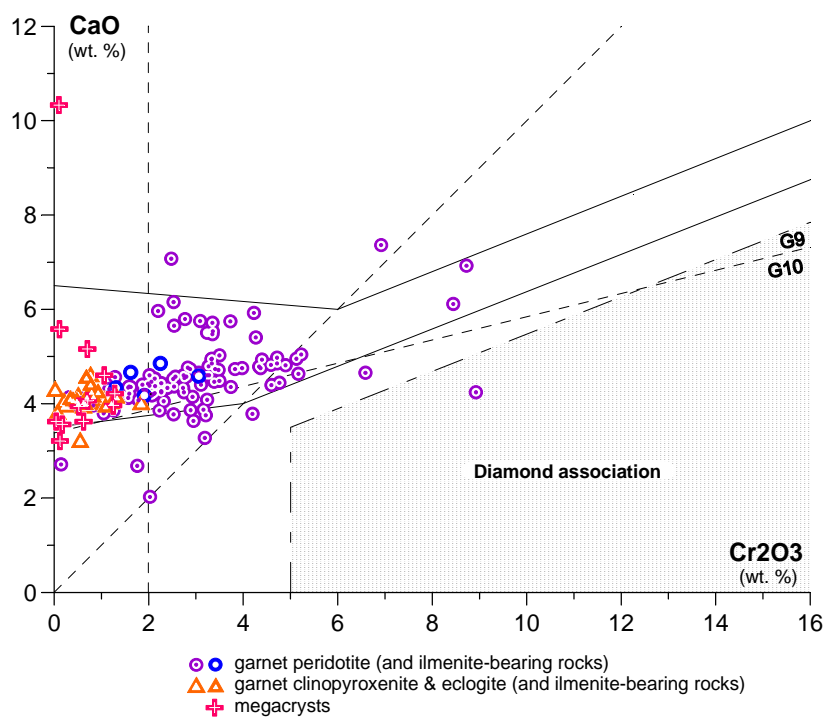

Chemical composition of the garnet

Clinopyroxene from petrologically different nodules in the Nyurbinskaya pipe has a quite constant composition, with a high $\mathrm{Ca}$ index, higher than average $\mathrm{Na}$ and $\mathrm{Al}$ contents, lower than average $\mathrm{Fe}$ and $\mathrm{Mg}$ contents, and a varying $\mathrm{Cr}$ content, which is generally atypical of mantle nodules occurring in Yakutian and Archangelsk kimberlites.

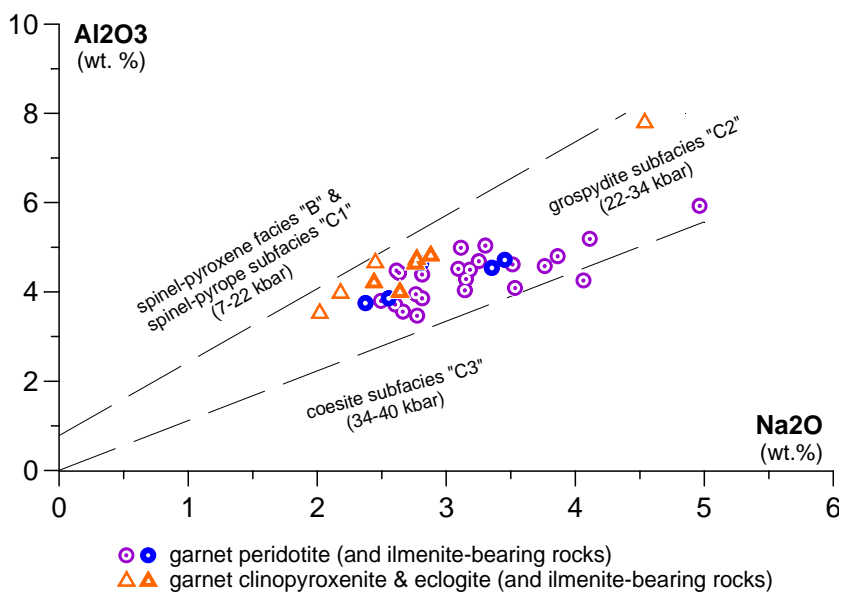

Chemical composition of the clinopyroxene

Picroilmenite from different mantle xenoliths is characterized by higher than average $\mathrm{TiO}_{2}$ and $\mathrm{MgO}$ contents, therewith being almost free of hematite 
component, thus sharply differing in composition from typical kimberlitic picroilmenite.

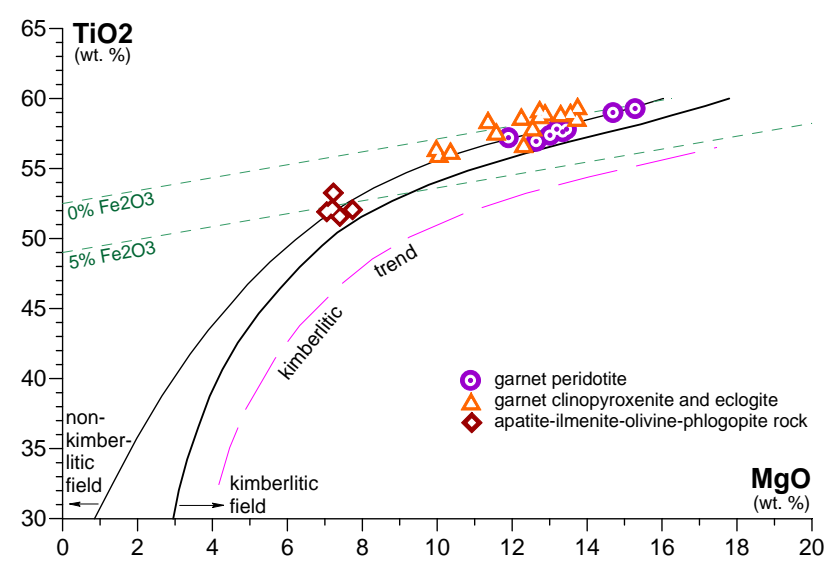

Chemical composition of the picroilmenite

Garnet peridotite and clinopyroxenite xenoliths are characterized by a narrow range of $\mathrm{TP}$ forming parameters: $768-1002^{\circ} \mathrm{C}$ and 29.8-40.5 kbar (according to the geothermobarometer proposed by Nikitina and Simakov, 1994 for the clinopyroxene + garnet paragenesis; 31 samples were analyzed). The behaviour of nodule forming parameters fits well to the $40 \mathrm{~mW} / \mathrm{m}^{2}$ conductive geotherm.

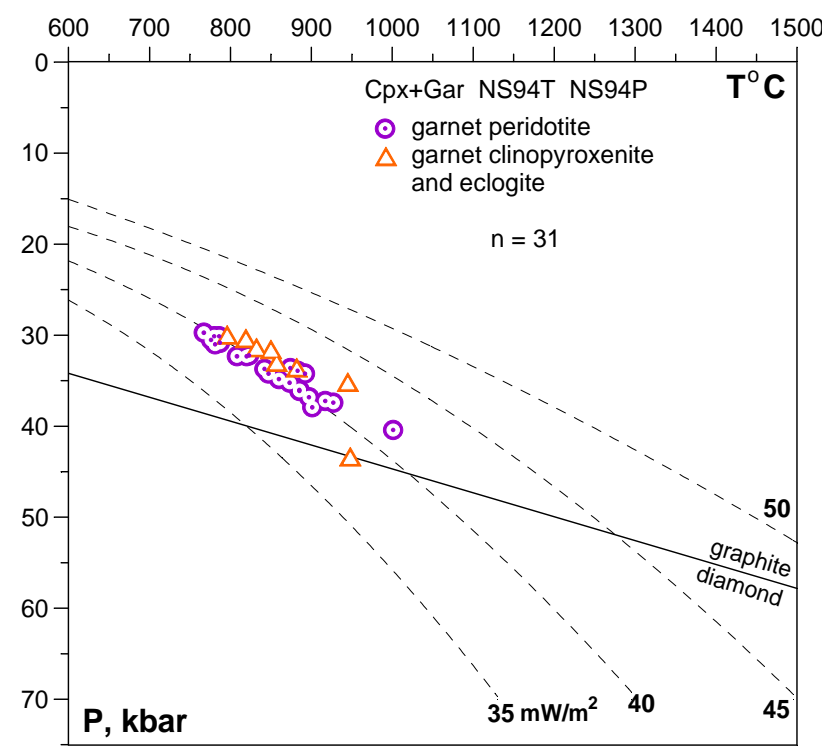

TP parameters of formation of mantle xenoliths from Nyurbinskaya pipe kimberlites

Metasomatism manifests itself in the examined nodules quite weakly, just as the development of phlogopite which could proceed almost concurrently with the formation of high-K kimberlitic melts.
The abundance and characteristic size of mantle xenoliths and the sharp predominance of garnet peridotite makes the Nyurbinskaya pipe kimberlites similar to kimberlite rocks from other Ykutian kimberlite fields. Along with this, kimberlites of the Nyurbinskaya pipe differ drastically from other Yakutian kimberlites by their high chrome spinel peridotite content, and by the presence of picroilmenite and clinopyroxene with peculiar mineral chemistry in mantle xenoliths, and absence of characteristic picroilmenite megacrysts.

Kimberlite pipes of the Nakyn field appear to be older than other Yakutian diamondiferous kimberlite pipes. Their peculiar geochemical and mineralogical features might reflect the early, relict condition of the lithospheric mantle, somewhat primitive, yet unaffected by a Fe-Ti mantle metasomatism from a Late Devonian asthenospheric diapir (mantle plume) so intense as was the case with mantle substrate of younger kimberlites in the Malo-Botuobinsky, DaldynAlakitsky and Verkhne-Munsky districts. This is why the direct examination of mantle rock fragments from kimberlites of the Nakyn field is undoubtedly of interest as an investigation of relict rocks characterizing the zones that previously existed in the upper mantle but than vanished as a result of complete transformation in later geological events. This $\underline{\text { direct }}$ examination of mantle rock fragments is no less (and, maybe, even more) important and interesting than the indirect study of mantle rocks through the medium of geochemical and isotopic characteristics of their host kimberlites.

\section{References}

Nikitina L.P. and Simakov S.K., 1994. TERRA nova. Fifth International EMPG Symposium. V. 6., 34.

Pollack H.N. and Chapman D.S., 1977. On the regional variation of heat flow, geotherms, and lithospheric thikness. Tectonophysics.V. 38., 279-296.

Sablukov S.M., Banzeruk V.I., Sablukova L.I., Stegnitskij Ju.B., Bogomolov E.S., Lebedev V.A., 2007. Ancient age of the Nakyn field kimberlites (Yakutia) - one of the reasons of an originality of their material structure // VIII International conference «New ideas in sciences about the Earth». Moscow. Reports. T. 5, 209212.

Sobolev, N.V., 1974. The deep seated inclusions in kimberlites and the problem of the upper mantle composition. Publishing House "Nauka", Siberian Branch, Novosibirsk, 264 (in Russian).

Wyatt, B.A, Baumgartner, M., Ancar, E. and Grutter, H., 2004. Compositional classification of "kimberlitic" and "non-kiberlitic" ilmenite //8th International Kimberlite Conference Selected Papers. Volume 2. Lithos 77, 819-840 